\title{
Growth and Distributive Effects of Public Infrastructure Investments in China
}

\author{
Yumei Zhang, Xinxin Wang, and Kevin Chen
}

\section{Introduction}

China has recently been spending more than $10 \%$ of total annual government expenditures on public infrastructure. In late 2008, when the global financial crisis occurred, a four trillion yuan package was put into action to stimulate domestic economic growth. Public infrastructure investment in 2009 and 2010 was respectively $60 \%$ and $80 \%$ higher than in 2008. China has managed to sustain rapid economic growth in recent years. However, disparities between rich and poor have risen, and China has become one of the most unequal countries in the world. Despite high overall economic growth rates, the Chinese government is becoming increasingly concerned about high and rising income inequality. Reducing poverty and inequality through inclusive growth has become a major mandate of development policy. President $\mathrm{Hu}$ Jintao formally endorsed inclusive growth as a national development strategy at the Asia-Pacific Economic Cooperation (APEC) in November, 2009.

Adequate infrastructure is critical for ensuring the effective functioning of the economy. Well-developed infrastructure can reduce the effect of distance between regions, integrate the national market and connect it to markets in other countries and regions at a low cost. China's 12th Five-Year Plan (2011-2015) emphasizes the need to "establish the sustainable basic public service system, and improve the ability to safeguard and promote equal access to basic public services," to "strengthen rural infrastructure and public services" and to "improve the quality and efficiency of

\footnotetext{
Y. Zhang

Agricultural Information Institute, Chinese Academy of Agricultural Sciences, Beijing, China

X. Wang

School of Economics and International Trade, Zhejiang University of Finance \& Economics, Hangzhou, China

K. Chen $(\bowtie)$

ICARD, with Chinese Academy of Agricultural Sciences, International Food Policy

Research Institute, Beijing, China

e-mail:k.chen@cgiar.org
} 
investment." The Premier of China, Wen Jiabao, in January of 2012 referred to the need to "continuously improve basic infrastructure in rural areas" in his latest speech "The path of Chinese agriculture and rural development," where he promoted the role of public finance through construction of public infrastructure to improve people's social welfare. The quality and reach of infrastructure networks are believed to not only impact economic growth but also to help reduce income inequality and poverty in a variety of ways (WEF 2011). In other words, public infrastructure investment (PII) can be viewed as an inclusive growth strategy.

Most existing studies on PII have focused on its impacts on economic growth (such as Ma et al. 2001; Liu 2003; Demurger 2001). Only a handful of academic studies have looked at the distributive effect of PII. Fan et al. (2002) and Gao and Li (2006) analyzed the poverty reducing effects of infrastructure in rural China. Zhang and Wan (2004) identified the specific role of rural infrastructure, shedding new light on how to allocate limited public resources to promote both growth and regional equity. The main methods used to analyze the impacts of public infrastructure are econometric tools and a computable general equilibrium (CGE) model.

This chapter assesses both the growth and distributive effects of PII in China using an integrated intertemporal dynamic model and a microsimulation model - it is useful to note that the analysis presented in this chapter is the first application of such an integrated CGE and microsimulation model to the case of China.

We employ an intertemporal dynamic general equilibrium model with public infrastructure capital and heterogeneous consumers and firms (constrained and non-constrained) as done by Dissou and Didic (2011). The Chinese inter-temporal CGE model is used to analyze the macro effects of the increase in PII. Under a top-down fashion and following the methodology presented in Cockburn et al. (2011), the changes predicted by the macroeconomic model are transmitted to the microsimulation module to simulate the poverty and distributive effects generated by the PII. Two policy scenarios are constructed to compare the effects of different PII financing mechanisms.

The paper is organized as follows: the section "Country Context and Infrastructure Status" introduces the country context and PII in China, then the section "Theoretical Frameworks, Data and Parameters" provides a quick overview of the theoretical models, discusses the data and the parameters, and presents the simulation scenarios. The results are discussed in the section "Discussion of Results", and conclusions and policy implications are summarized in the final section.

\section{Country Context and Infrastructure Status}

\section{China Context}

China has experienced unprecedented economic growth, with average annual growth of $10 \%$ since 1978 (Fig. 1). In 2010, the GDP of China was about 40.12 trillion yuan (about \$5.9 trillion), ranking China as the 2nd largest economy in the world after the 


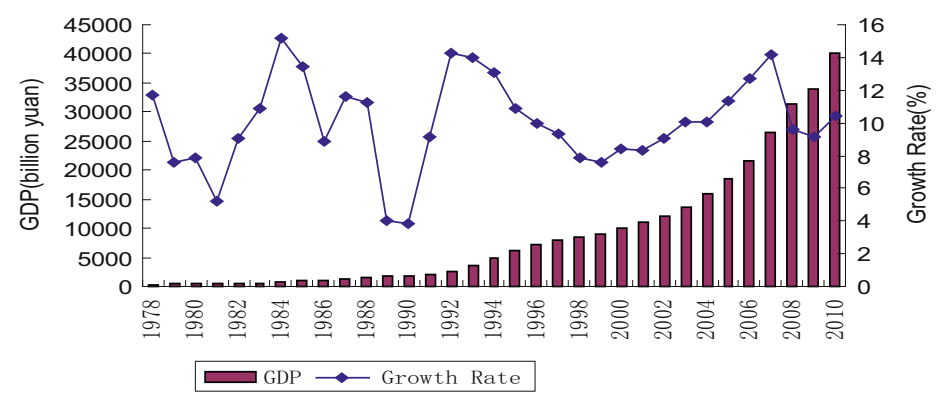

Fig. 1 GDP and real GDP growth in China, 1978-2010 (Source: China Statistical Yearbook 2011)

United States (WEF 2011). China has also become the second largest trading country in the world, with the total value of imports and exports totaling $\$ 2.97$ trillion, or 143 times more than in 1978, for an average annual growth rate of $16.8 \%{ }^{1}$

This rapid economic growth supported swift gains in household income, and living standards improved significantly. For example, urban and rural households respectively had incomes of 19,109 yuan and 5,919 yuan in 2010, nearly ten times their levels in 1978. The annual average real growth rate of per capita income for both urban and rural households was over $7 \%$. The share of the household budget spent on food consumption decreased from $57.5 \%$ in 1978 to $35.7 \%$ in 2010 in urban areas, while the corresponding decline was from $67.7 \%$ in 1978 to $41.1 \%$ in 2010 among rural households. Meanwhile, China has achieved tremendous success in poverty reduction over the past three decades. The official poverty lines show an incidence of poverty that declines from $33 \%$ in 1978 to $2.8 \%$ in 2010 . China has the largest population in the world (1.34 billion in 2010), but is ranked just 121st of 215 countries in terms of per capita gross national income (GNI) (NBS 2011). China still has the second largest number of poor people in the world, after India, with about 129.6 million undernourished people in 2004-2006 (FAO 2011). What is more disturbing is that China's economic growth has been accompanied by rising inequality. The gaps between rural and urban areas and between the western and eastern regions of China have increased under rapid economic growth. For instance, the urban to rural household income ratio increased from 2.6 times higher in 1978 to 3.2 times higher in 2010. The Gini coefficient reached 0.47 in China in 2009 (World Bank 2009), well exceeding the "international alerting line" of 0.4. China has become one of the most unequal countries in the world.

\section{Infrastructure Status}

China's infrastructure has improved significantly over the past three decades. This includes progress towards increasing public spending on infrastructure at a level

\footnotetext{
${ }^{1}$ http://www.gov.cn/zwgk/2011-12/07/content_2013475.htm
} 
Table 1 Length of transportation routes $(1,000 \mathrm{~km})$

\begin{tabular}{llclcc}
\hline Year & $\begin{array}{l}\text { Railways in } \\
\text { operation }\end{array}$ & Highways & $\begin{array}{l}\text { Navigable inland } \\
\text { waterways }\end{array}$ & $\begin{array}{l}\text { Total commercial } \\
\text { air routes }\end{array}$ & $\begin{array}{l}\text { Petroleum and gas } \\
\text { pipelines }\end{array}$ \\
\hline 1978 & 51.7 & 890.2 & 136.0 & 148.9 & 8.3 \\
1990 & 57.9 & $1,028.3$ & 109.2 & 506.8 & 15.9 \\
2000 & 68.7 & $1,402.7$ & 119.3 & $1,502.9$ & 24.7 \\
2010 & 91.2 & $4,008.2$ & 124.2 & $2,765.1$ & 78.5 \\
\hline
\end{tabular}

Source: China Statistical Yearbook (2011)

that is more in line with China's development needs (OECD 2006). China overall competiveness index ranked 26th among 142 economies and the competitiveness index of infrastructure ranked 44th (WEF 2011).

\section{Transportation}

China's transportation system has improved greatly with increased public investment in transportation infrastructure. In 2010, a total of 91.2 thousand $\mathrm{km}$ of railway were in operation, or 1.76 times that in 1978. The highway is the fastest growing line of transportation, with a length of 4 million kilometers in 2010, or more than 4.5 times that of 1978 . Commercial (civil) aviation routes have also improved substantially over this period of time, with a total length of 18.6 times further in 2010 than in 1978. This major increase in railways, highways and commercial aviation may have reduced the relative significance of the navigable inland waterways, which has hardly changed in the past 30 years (Table 1).

\section{Electricity}

In 2010, total electricity output was about 3,703 Twh in China. To improve the living standard of rural households, the Chinese government now pays more attention to public infrastructure in rural areas. Irrigated land area totalled 60.35 million hectares in 2010, or $34.2 \%$ more than in 1978 . Hydropower stations in rural areas numbered 44,815 in 2010, and had a generating capacity of 59.24 Gwh, or 26 times that of 1978. The total amount of electric power generated in rural area was 204.4 Twh in 2010 (Table 2).

\section{Postal and Telecommunication Services}

In 2010, each post office served an average of about 18,000 people, and nearly $98.96 \%$ of administrative villages had a post office. Telephones (including mobile telephones) numbered about 86.41 sets per 100 persons. Broadband internet access was available in $80.11 \%$ of administrative villages (NBS 2011). The data shows great improvements of postal and telecommunication services in China (Table 3). 
Table 2 Irrigation, hydropower stations and power generation in rural China

\begin{tabular}{|c|c|c|c|c|}
\hline \multirow[b]{2}{*}{ Year } & \multirow{2}{*}{$\begin{array}{l}\text { Irrigated area } \\
\text { (millions hectares) }\end{array}$} & \multicolumn{2}{|c|}{ Hydropower stations } & \multirow{2}{*}{$\begin{array}{l}\text { Kwh of electric powe } \\
\text { generation (Twh) }\end{array}$} \\
\hline & & Number & Generating capacity $(\mathrm{Gw})$ & \\
\hline 1978 & 44.9650 & 82,387 & 2.284 & \\
\hline 1990 & 47.4031 & 52,387 & 4.288 & 418.1 \\
\hline 2000 & 53.8203 & 29,962 & 6.985 & 875.5 \\
\hline 2005 & 55.0293 & 26,726 & 10.992 & $1,357.2$ \\
\hline 2006 & 55.7505 & 27,493 & 12.430 & $1,483.6$ \\
\hline 2007 & 56.5183 & 27,664 & 13.666 & $1,634.6$ \\
\hline 2008 & 58.4717 & 44,433 & 51.274 & $1,627.6$ \\
\hline 2009 & 59.2614 & 44,804 & 55.121 & $1,567.2$ \\
\hline 2010 & 60.3477 & 44,815 & 59.240 & $2,044.4$ \\
\hline
\end{tabular}

Source: China Statistical Yearbook (2011)

Table 3 Level of postal and telecommunication services (2005-2010)

\begin{tabular}{|c|c|c|c|c|c|c|}
\hline Item & 2005 & 2006 & 2007 & 2008 & 2009 & 2010 \\
\hline Number of post offices & 65,917 & 62,799 & 70,655 & 69,146 & 65,672 & 75,739 \\
\hline $\begin{array}{l}\text { Length of postal routes and rural delivery } \\
\text { routes (millions } \mathrm{km})\end{array}$ & 6.9715 & 6.9364 & 7.1705 & 7.3500 & 7.704 & 8.326 \\
\hline $\begin{array}{l}\text { Percentage of administrative villages with } \\
\text { post office }(\%)\end{array}$ & 98.96 & 99.40 & 98.40 & 98.50 & 98.80 & 98.96 \\
\hline Telephones (including mobiles), /100 persons & 57.22 & 63.40 & 69.45 & 74.29 & 79.89 & 86.41 \\
\hline
\end{tabular}

Data sources: China Statistical Yearbook (2011)

\section{Public Infrastructure Investment}

As data on PII is not readily available, researchers must rely on data from different sources. OECD (2006) used total fixed asset investment to analyze the main components of government capital spending including transportation, agriculture and education. Liu (2009) used the state's budgeted investment in fixed assets as the public infrastructure investment. Song (2011) chose infrastructure investments in just two sectors: (1) transportation, storage, postal and telecommunication services; and (2) production and supply of electricity, gas and water. In this study, we take the state's budget investment in fixed assets as a measure of PII. Sources of funds for investment in fixed assets are categorized as funds from the state budget, domestic loans, foreign investment, self-raised funds and others.

In China, public infrastructure investment increased very quickly, especially after 1997, the year of the Asian financial crisis. At that time, the government increased fiscal expenditures on public infrastructure to stimulate domestic demand and to promote economic growth. PII increased from 69.7 billion yuan in 1997 to $1,467.8$ billion yuan in 2010, for an average annual growth of real PII of $24.55 \%$ over 1997-2010. The same reasoning was also behind increased public investment in response to the 2008 global financial crisis. The Chinese government formulated a stimulus package that injected 4 trillion yuan to stimulate the economy. Public 
Table 4 Public expenditures on infrastructure in China, 1997-2010

\begin{tabular}{lccll}
\hline & \multicolumn{2}{l}{$\begin{array}{l}\text { Public infrastructure expenditures } \\
\text { (PII, billions yuan) }\end{array}$} & PII as share of total \\
Year & Current price & 2005 constant price & government expenditures (\%) & PII/GDP (\%) \\
\hline 1997 & 69.7 & 73.2 & 7.5 & 0.9 \\
1998 & 119.7 & 126.7 & 11.1 & 1.4 \\
1999 & 185.2 & 198.8 & 14 & 2.1 \\
2000 & 211.0 & 225.5 & 13.3 & 2.1 \\
2005 & 415.4 & 415.4 & 12.2 & 2.2 \\
2006 & 467.2 & 460.3 & 11.6 & 2.2 \\
2007 & 585.7 & 550.6 & 11.8 & 2.2 \\
2008 & 795.5 & 706.1 & 12.7 & 2.5 \\
2009 & $1,268.6$ & $1,134.1$ & 16.6 & 3.7 \\
2010 & $1,467.8$ & $1,270.3$ & 16.3 & 3.7 \\
\hline
\end{tabular}

Source: China Statistical Yearbook (2011)

infrastructure investment was $60 \%$ higher in 2009 than in 2008. PII as a share of total government expenditures also increased from $7.5 \%$ in 1997 to $16.6 \%$ in 2009. The PII-to-GDP ratio was also higher, at $3.7 \%$ in 2009 and 2010 (Table 4).

\section{Theoretical Frameworks, Data and Parameters}

\section{Overview of the Theoretical Models}

This paper applies a macro-micro simulation methodology in the context of a computable general equilibrium (CGE) model to analyze the impacts of an increase in public infrastructure investment. CGE models are able to capture the complex direct and indirect interactions between public infrastructure investment, factor markets, commodity markets, households, the government, private firms and foreign markets. However, CGE models cannot fully capture the heterogeneous impact on Chinese individuals and households and, in particular, are not able to take into account the inequality within each group. On the contrary, the microeconomic component can capture the full heterogeneity of economic agents by modelling different individual and household behaviors based on household survey data. Specifically, the effects of the increase in public infrastructure investment on households' welfare are captured through changes in wage and non-wage revenues, commodity prices and savings. A combination of the macro and micro components is needed to capture the impacts of the additional public infrastructure investment on households and to identify whether the increased public infrastructure investment affects all households across the country in the same manner. The CGE model and the micro-econometric behavioral model are linked in a "top-down" fashion to assess the various impacts of public infrastructure on households. We will now summarize the theoretical models and elaborate on some issues which are specific 
to the case of China. The macro- and micro-simulation models are presented in chapter "The Growth and Distributive Impacts of Public Infrastructure Investments in the Philippines". For interested readers, the complete specifications of the CGE model can be found in Dissou and Didic (2011) while the full description of the microsimulation model is in Cockburn et al. (2011).

\section{CGE Database: SAM and Parameters}

The dataset used to calibrate the dynamic CGE model to the benchmark equilibrium is the Social Accounting Matrix (SAM). The SAM is built using the 2007 input-output (IO) table from the China National Bureau of Statistics. To solve the model conveniently, we aggregate the 42 sectors from the IO table into 17 sectors. The data in the SAM are mainly from the China Statistical Yearbook (2010) and China Financial Yearbook (2008).

The sectoral structure of the Chinese economy, based on the 2007 SAM, is presented in Table 5. The sectors with the largest value added are other services, agriculture, and machinery and equipment. Household consumption is much more targeted toward agriculture, food processing, retail and catering, and other services than toward other sectors. Construction is the sector with the highest total investment, with more than half $(55.81 \%)$ of total investments being allocated to this sector. Machinery and equipment comes second at $33.67 \%$ of total investment. Machinery and equipment is the largest export and import sector. The textiles sector is also fairly export-oriented, with $14.54 \%$ of its production being exported. The mining sector is fairly dependent on imports, and takes in $13.97 \%$ of imports.

Most of the parameters can be calculated directly from the SAM, while the remaining elasticity parameters are obtained from the literature. The elasticity of substitution of CES production, and of the Armington function and CET functions, are obtained from Zhai and Hertel (2005). All the parameters used in the CGE model are presented in the appendix (Table A1). As in most studies, the adjustment cost parameter in the installation cost function is set to 2. The effects of long-run population growth are adjusted to $2.5 \%$ to account for growth of the population $(0.5 \%)$ and labour productivity $(2.0 \%)$.

The model accounts for the capital stock in the production function, but capital is not observed directly in many sectors. This leads us to use the growth rate approach to derive the capital stock in each sector with investment data from the China Statistical Yearbook. We then adjust the data on the basis of the capital stock study by $\mathrm{Wu}$ (2009), who estimated the stocks of capital in agriculture, manufacturing and services.

Public capital output elasticities are estimated to range anywhere from 0.06 to 0.59 across countries (Ratner 1983; Munnell 1990; Argimon et al. 1994; Otto and Voss 1994; Ramirez 2002). We choose the output elasticity of public capital as estimated in Song (2011), who uses a three-step non-stationary panel analytical procedure and obtains a moderate value of 0.15 for China. This estimate is used for 
Table 5 Sectoral structure of Chinese economy based on 2007 China SAM (\%)

\begin{tabular}{|c|c|c|c|c|c|c|}
\hline Sectors & $\begin{array}{l}\text { Value } \\
\text { added }\end{array}$ & $\begin{array}{l}\text { Household } \\
\text { consumption }\end{array}$ & $\begin{array}{l}\text { Government } \\
\text { consumption }\end{array}$ & $\begin{array}{l}\text { Total } \\
\text { investment }\end{array}$ & Exports & Imports \\
\hline Agriculture & 10.77 & 11.55 & 0.97 & 1.01 & 0.70 & 3.15 \\
\hline Mining & 5.19 & 0.15 & 0.00 & 0.00 & 0.67 & 13.97 \\
\hline Food processing & 3.83 & 17.28 & 0.00 & 0.00 & 2.00 & 2.14 \\
\hline Textile & 3.36 & 6.33 & 0.00 & 0.00 & 14.54 & 1.93 \\
\hline Other manufacture & 4.23 & 2.40 & 0.00 & 1.86 & 6.31 & 3.69 \\
\hline $\begin{array}{l}\text { Electric power, heat } \\
\text { power and water }\end{array}$ & 3.52 & 2.77 & 0.00 & 0.00 & 0.07 & 0.02 \\
\hline $\begin{array}{l}\text { Coking, gas, } \\
\text { petroleum }\end{array}$ & 1.49 & 1.11 & 0.00 & 0.00 & 0.80 & 1.96 \\
\hline Chemical industry & 4.73 & 2.43 & 0.00 & 0.00 & 7.58 & 12.30 \\
\hline $\begin{array}{l}\text { Nonmetallic mineral } \\
\text { products }\end{array}$ & 2.35 & 0.29 & 0.00 & 0.00 & 1.55 & 0.51 \\
\hline Metals, metal products & 5.87 & 0.43 & 0.00 & 0.90 & 9.12 & 6.63 \\
\hline $\begin{array}{l}\text { Machinery and } \\
\text { equipment }\end{array}$ & 10.53 & 6.80 & 0.00 & 33.67 & 42.35 & 45.54 \\
\hline Construction & 5.46 & 0.97 & 0.00 & 55.81 & 0.43 & 0.30 \\
\hline Transport & 7.89 & 5.58 & 4.61 & 1.42 & 4.69 & 2.03 \\
\hline $\begin{array}{l}\text { Retail and catering } \\
\text { services }\end{array}$ & 8.61 & 13.98 & 0.00 & 1.79 & 4.97 & 0.71 \\
\hline Real estate & 6.06 & 9.10 & 1.62 & 3.23 & 3.36 & 3.26 \\
\hline Finance & 5.05 & 4.29 & 0.77 & 0.00 & 0.09 & 0.17 \\
\hline Other services & 11.06 & 14.53 & 92.03 & 0.30 & 0.78 & 1.70 \\
\hline
\end{tabular}

Data sources: Calculated from input-output tables of China (2007)

all 17 sectors because we do not have sector-specific elasticities. Sensitivity analysis was performed on the chosen elasticity to assess the robustness of the results.

\section{Household Data}

The household survey data was produced by the Chinese Household Income Project (CHIP) of Inter-University Consortium for Political and Social Research. Although a 2007 survey was also carried out, only the 2002 dataset was made publicly available. The 2002 CHIP data was collected through a series of questionnairebased interviews conducted in rural and urban areas towards the end of 2002, and covered three types of households: urban, rural and migrant. There are a total of 6,835 urban households, 9,200 rural households and 2,000 migrant households included in the survey. The total number of individuals covered by the sample is 37,969. The microsimulations are done on each of these different groups. Sample weights are calculated according to the share of the urban, rural and migrant populations in the total population.

Understandably, it is less than desirable to use 2002 data to estimate the current situation of poverty and inequality in China. In order to capture the recent situation, 
we update household consumption expenditures to 2009 using aggregate national household survey data available from the China Statistical Yearbooks. The mean growth rates between 2002 and 2009 for each consumption expenditure category of rural and urban households are calculated by income quintile. The same growth rates are then assumed to hold for the consumption expenditure item in that quintile of rural or urban households. The itemized consumption expenditures of migrant households are updated using information that can be compared to urban households.

Coherently with the CGE model, we divide households into constrained and non-constrained according to their ability to borrow or lend. If the household can participate in public or private credit markets, then the household is assumed to have the ability to smooth consumption and is considered as non-constrained, otherwise the household is constrained. We estimate the probability of being a constrained or non-constrained household using household survey data conducted by CHIP. From the survey data we use, we find that about $75 \%$ of households are constrained and the remainder are non-constrained. The results are largely in line with Zhang and Wan (2004), who estimated that $70 \%$ of households were constrained in 1984-1998 CHIP data.

Finally, before estimating the poverty headcount index, the poverty line must be chosen. The official Chinese poverty line for rural households was 1,196 Yuan per year in 2009. According to this definition, there were about 35.97 million poor people, for a poverty incidence of around $3.6 \%$ in rural China. The Chinese official poverty line is too low and poverty is grossly underestimated. For comparison, the World Bank poverty line of $\$ 1.25$ per day, or about 2,085 PPP Yuan per year in 2009 is used too.

Since the poverty lines for urban and migrant households are not published by the Chinese government, the difference in living costs between rural and urban areas is used to set the poverty lines for urban and migrant households. According to the World Bank (2009), the living cost in urban areas was estimated at about 1.5 times that of rural areas. The poverty line for urban and migrant households is thus set at 1.5 times that used for rural areas.

As seen above, the official Chinese poverty line yields a national poverty headcount index of about $3 \%$ and most of the poor are located in rural areas. When the international poverty line is used, the poverty headcount index rises to $28.51 \%$ for rural households, $2.36 \%$ for migrant households and $6.60 \%$ for urban households. However, despite the large difference in the results for each of the two poverty lines, we found fairly consistent poverty trends under the different poverty lines. Given that China increased its poverty line substantially in 2011 to 2,300 Yuan per year, we opt to estimate poverty with the international poverty line.

\section{Simulation Scenarios}

We first analyze the broader economic impacts of increased public infrastructure investment under different financing mechanisms. We then simulate the impacts of 
higher public infrastructure investment on households' consumption, poverty and inequality.

As public infrastructure investment in China increased rapidly during the last decade, we consider the case of a $20 \%$ increase in the public infrastructure investment-to-GDP ratio. Fixed government savings provides the macro closure. In the first scenario, we assume that the increase in public infrastructure investment is financed by foreign borrowing and, in the second, we assume that the increase is financed by higher production taxes. In the second scenario, a uniform percentage increase in production taxes was imposed proportionately on all constrained and non-constrained firms. This means that, in the second scenario, the initial increase in public infrastructure investment is entirely financed by an increase in the production tax rate.

In the microsimulation, the macro impacts of the two simulations are generated from the CGE model. The changes in the poverty headcount index and Gini coefficients are calculated under both simulations across different timeframes.

We quantify the aggregate and sectoral effects of variables over time as percentage changes with respect to their baseline values and report these effects for the following periods: the first period (the first year following the shock), the short-run (the 5th year), the intermediate run (20th year), and the very long-run (the 100th year). The values obtained in the 100th year denote the steady-state values of the model.

\section{Discussion of Results}

\section{Macroeconomic Effects}

\section{Simulation 1: Increase in Public Infrastructure Investment Under Foreign Financing}

Aggregate effects: The macroeconomic results are shown in Table 6. In the first period, government investment increases by $19.8 \%$ and the public infrastructureto-GDP ratio increases by $20 \%$. Foreign borrowing as a share of GDP increases by $0.69 \%$ to balance the government's account. Public infrastructure investment in the first period adds to the level of public capital stock only in the next period.

The increase in public infrastructure investments drives demand for labour and capital, raising the wages and the rental rate capital goods, respectively by $0.41 \%$ and $0.51 \%$ in the first period. Both the constrained and non-constrained households increase their consumption owing to higher labour and capital income. However, in contrast to constrained households, the non-constrained households in anticipation of higher future productivity and capital returns increase their investment in private capital by about $2 \%$ in the first period.

In the immediate period, firms face higher labour and capital costs due to rising wage rates and prices for capital goods. The increased input costs are passed onto 
Table 6 Macro-simulation results under scenario 1 and 2 (\% deviations from baseline)

\begin{tabular}{|c|c|c|c|c|c|}
\hline \multirow[b]{3}{*}{ Scenarios } & \multicolumn{5}{|c|}{ Variables periods } \\
\hline & \multicolumn{3}{|c|}{ Foreign financing } & \multicolumn{2}{|c|}{ Production tax financing } \\
\hline & $\begin{array}{l}\text { First } \\
\text { period } 1\end{array}$ & $\begin{array}{l}\text { Short } 1 \\
\text { run } 1\end{array}$ & $\begin{array}{l}\text { Long } \\
\text { run }\end{array}$ & $\begin{array}{l}\text { First } \\
\text { periodShort run }\end{array}$ & $\begin{array}{l}\text { Long } \\
\text { run }\end{array}$ \\
\hline Real GDP & -0.01 & 0.57 & 3.86 & $-0.06 \quad 0.03$ & 4.32 \\
\hline Consumption price index & 0.39 & 0.40 & 0.14 & $0.08 \quad 0.10$ & 0.27 \\
\hline Wage rate & 0.41 & 1.18 & 4.81 & $-0.51 \quad 0.07$ & 5.74 \\
\hline $\begin{array}{l}\text { Rental rate of capital, constrained } \\
\text { household/firm }\end{array}$ & 0.18 & 0.80 & 0.07 & $\begin{array}{ll}-0.47 & 0.08\end{array}$ & 0.13 \\
\hline Price of capital good & 0.51 & 0.38 & -0.09 & $0.20 \quad 0.17$ & -0.03 \\
\hline Real exchange rate & -0.40 & -0.36 & 0.03 & $-0.12-0.12$ & -0.06 \\
\hline Government revenues & 2.32 & 2.45 & 2.84 & $1.98 \quad 2.07$ & 3.08 \\
\hline Total aggregate consumption & 0.61 & 0.99 & 3.25 & $0.46 \quad 0.69$ & 3.78 \\
\hline $\begin{array}{l}\text { Total consumption of non-constrained } \\
\text { households }\end{array}$ & 2.22 & 2.21 & 2.47 & $2.84 \quad 2.82$ & 2.65 \\
\hline $\begin{array}{l}\text { Total consumption of constrained } \\
\text { household }\end{array}$ & 0.31 & 0.86 & 3.72 & $-0.47-0.12$ & 4.54 \\
\hline Total investment & 1.92 & 2.86 & 5.68 & $0.67 \quad 1.64$ & 6.71 \\
\hline Government investment & 19.84 & 20.70 & 24.89 & 19.7920 .38 & 25.56 \\
\hline Total private investment & 0.97 & 1.92 & 4.67 & $-0.34 \quad 0.65$ & 5.72 \\
\hline Non-constrained firms & 2.17 & 3.39 & 5.56 & $0.01 \quad 1.61$ & 6.90 \\
\hline Constrained firms & -0.21 & 0.48 & 3.81 & $-0.68-0.29$ & 4.56 \\
\hline Total aggregate capital stock & 0.00 & 0.57 & 5.59 & $0.00 \quad 0.27$ & 6.43 \\
\hline Public capital & 0.00 & 5.29 & 24.81 & $0.00 \quad 5.25$ & 25.31 \\
\hline Total private capital stock & 0.00 & 0.32 & 4.57 & $0.00 \quad 0.01$ & 5.43 \\
\hline Non-constrained firms & 0.00 & 0.64 & 5.41 & $0.00 \quad 0.17$ & 6.47 \\
\hline Constrained firms & 0.00 & 0.02 & 3.75 & $0.00-0.14$ & 4.44 \\
\hline Total exports & -1.91 & -1.13 & 4.59 & $-1.13-0.72$ & 4.95 \\
\hline Total imports & 1.16 & 1.81 & 4.38 & $0.37 \quad 0.95$ & 5.18 \\
\hline $\begin{array}{l}\text { Disposable income, constrained } \\
\text { households }\end{array}$ & 0.31 & 0.86 & 3.72 & $-0.47-0.12$ & 4.54 \\
\hline Labour income, constrained households & 0.41 & 1.18 & 4.81 & $-0.51 \quad 0.07$ & 5.74 \\
\hline Capital income, constrained households & 0.18 & 0.82 & 3.82 & $-0.47-0.07$ & 4.57 \\
\hline Saving, constrained households & 0.31 & 0.86 & 3.72 & $-0.47-0.12$ & 4.54 \\
\hline $\begin{array}{l}\text { Additional foreign borrowing } \\
\text { (\% of GDP })\end{array}$ & 0.69 & $0.63-$ & -0.28 & & \\
\hline Increase in production tax rate $(\%)$ & & & & $3.67 \quad 4.01$ & -2.25 \\
\hline
\end{tabular}

Source: Model results

consumers, driving up domestic prices. In international markets, imported commodities become cheaper due to a $0.40 \%$ increase in the real exchange rate. Imports increase by $1 \%$, not only due to the higher real exchange rate, but also due to the increase in demand induced by higher public investment. Exports drop $2 \%$ due to higher domestic prices and the higher real exchange rate. Weak Dutch Disease effects are thus observed in the Chinese economy in the immediate period 
following increased public infrastructure investment financed by foreign borrowing. Real GDP falls by $0.01 \%$ in the first period.

In the short and the long-run, increased public investment leads to an accumulation of the public capital stock and ongoing improvements in the productivity of labour and private capital. The public capital stock respectively increases by $5.29 \%$ and $24.81 \%$ in the short and the long-run. The stock of private capital also increases by $0.32 \%$ in the short-run and $4.58 \%$ in the long-run. Wages in the short and the long-run respectively rise by $1.18 \%$ and $4.80 \%$ due to improved productivity.

The disposable income of constrained households rises, as do wages, respectively leading to short and long-run increases of $0.86 \%$ and $3.70 \%$. The consumption of non-constrained households becomes relatively higher (about $2 \%$ ) over the course of the simulation because they are able to smooth their consumption. Their total short and long run consumption respectively increase by $0.99 \%$ and $3.25 \%$.

Public investment also stimulates private investment via improved productivity. Both constrained and non-constrained firms increase their investments in the short and the long-run. Investment by constrained firms rises by $0.48 \%$ in the short-run and $3.80 \%$ in the long-run, while that of non-constrained firms rises even more: $3.39 \%$ in the short-run and $5.63 \%$ in the long-run. Total private investment rises by $1.92 \%$ in the short-run and $4.70 \%$ in the long-run.

In the international market, Dutch disease effects persist in the short-run due to lower exports and higher imports. However, these effects soften gradually and are completely eliminated in the long-run. Lower production costs and increased output improve the international competitiveness of domestic producers over time. At the same time, real exchange rate appreciation slows and becomes negative $(0.03 \%$ lower in the long run). It is interesting to note that exports and imports both increase in the long-run, respectively by $4.59 \%$ and $4.38 \%$.

Despite limited Dutch disease effects observed in the first period and in the short-run due to the continuous inflow of foreign finance, public infrastructure investments play a critical role in enhancing productivity and in stimulating consumption and investment over time. Real GDP is as much as $0.57 \%$ and $3.86 \%$ higher, respectively in the short and the long-run (see Fig. 2). In the long-run, the effects of increased public investment are substantial. The increase in public investment improves productivity and bolsters private investment. The long-run level of investment in constrained and non-constrained firms is respectively $3.81 \%$ and $5.56 \%$ higher than in the baseline. Both constrained and non-constrained households increase their consumption in the long-run, respectively by $3.72 \%$ and $2.47 \%$. Finally, GDP is as much as $3.86 \%$ higher relative to the baseline scenario.

Sectoral Effects: Public infrastructure investment generates an externality on firm technology and all sectors benefit equally from the increase in public infrastructure investment. There are also some sector-specific effects, especially in the first period and in the short-run.

In the first period, on the demand side, household income increases via rising wages and rents from capital goods. Their rising income allows consumption to increase across all sectors. Dutch disease effects resulting from increased inflows of 


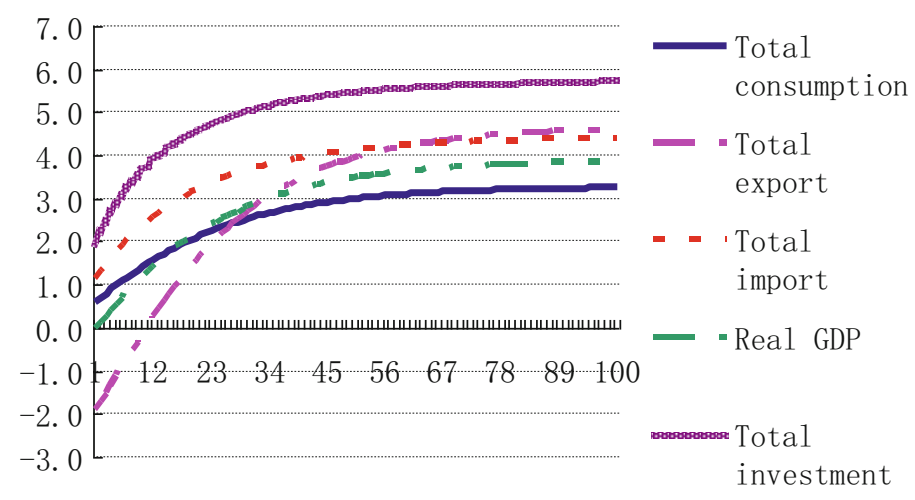

Fig. 2 GDP: demand side effects (international financing) (Source: Model results)

foreign finance cause real exchange rate appreciation, causing imports to rise in all sectors, while exports decline across all sectors. The export-oriented sectors lose their competitiveness in the international market. For example, textiles exports decline immediately by $4.06 \%$. There are also some shocks to the machinery and equipment sector, which is the largest sector for both imports and exports. Imports in the sector rise by $1.49 \%$ and its exports decline by $1.76 \%$.

On the supply side, both constrained and non-constrained firms increase their investment in the first period. Non-constrained firms reallocate their investments among sectors according to their rates of return. The nonmetallic mineral products sector attracts more private investment, for a $5.74 \%$ increase, while private investment in the chemical industry sector falls by $0.42 \%$. The same is observed for labour demand, where rising wages cause some workers to shift between sectors. For example, the textile sector's effective labour demand shrinks $2.49 \%$ due to a decline in its international competitiveness. The construction sector's labour demand increases by $3.08 \%$. There are also differing changes in the demand for intermediate goods. For example, the intermediate demand for nonmetallic mineral products rises by $1.23 \%$, while the intermediate use of textiles declines by $1.71 \%$.

As a result, a number of sectors gain from the increase in public investment under the foreign financing mechanism, but other sectors lose in the first period. Output in the construction sector increases most, by $1.81 \%$, followed by nonmetallic mineral products, with a $1.05 \%$ increase in sectoral output. Declining sectoral production of $2.22 \%, 0.55 \%$ and $0.49 \%$ was respectively recorded in the textiles, chemical industry, and machinery and equipment sectors. Any output changes in other sectors are smaller than those mentioned in the first period.

In the short and the long-run, sectoral productivity increases due to higher public investment and public capital. The negative effects on certain sectors gradually dissipate, and positive effects become increasingly more important over time. As a result, all sectors gain from increased public investment in the long-run. Total production in several sectors is boosted by more than $5 \%$ as a result of the policy: 
metal and metal product manufacturing $(+5.71 \%)$, nonmetallic mineral product manufacturing $(+5.46 \%)$, machinery and equipment manufacturing $(+5.22 \%)$ and real estate $(+5.15 \%)$. The textiles sector also gains from increased long-run public investment, with a $0.39 \%$ increase in its sectoral output, which is much less than in other sectors.

\section{Simulation 2: Increase in Public Infrastructure Investment Under Production Tax Financing}

In simulation 2, we assume that the increase in public infrastructure investment is financed by a production tax imposed on all firms, instead of foreign borrowing. In this case, the overall effects of increased public investment in infrastructure depends on trade-offs between the positive productivity effects of public infrastructure and the distortionary effects of the increased tax burden. The aggregate effects are presented in the last three columns of Table 7 . Certain results are similar to those obtained in the previous simulation, particularly in the long-run. However, there are notable differences between the two simulations in the early periods following increased investment in infrastructure.

Aggregate effects: In the first period, public investment increases by $19.79 \%$ and the production tax rate increases by $3.67 \%$ to balance government payments. The higher tax imposes an additional burden on firms and exerts negative shocks on the economy. Contrary to simulation 1 , the wage rate and the capital rental rate of constrained households respectively decline by $0.51 \%$ and $0.47 \%$ in the first period. As a result, the disposable income of constrained households is $0.47 \%$ lower relative to the baseline scenario. This negative effect on income leads constrained households to decrease their first-period consumption by $0.47 \%$ as well. However, the non-constrained households increase their first-period consumption by $2.84 \%$ due to their ability to smooth consumption. Due to decreased consumption of constrained households, total consumption in the first period rises by less than in the previous simulation.

Public investment appears to crowd out private investment in the first period. Total private investment falls by $0.34 \%$. This crowding out effect stems from the increase in the price of capital goods (which increases by $0.2 \%$ ) and a reduction in the income of constrained households. As a result, constrained firms reduce their investment by $0.68 \%$ in the first period. Due to the increase in both the production tax rate and the price of capital goods, the non-constrained firms barely increase their investment $(0.008 \%)$ in the first period. This is very different from the results of simulation 1 where total private investment increases by $0.97 \%$ in the first period.

In the international market, real exchange rates are $0.12 \%$ higher due to the increase in public investment, which stimulates a $0.3 \%$ increase in import demand, while it lowers export demand by $1.13 \%$ in the first period. As a whole, real GDP falls by $0.06 \%$ in the first period - a much steeper decline than registered in scenario 


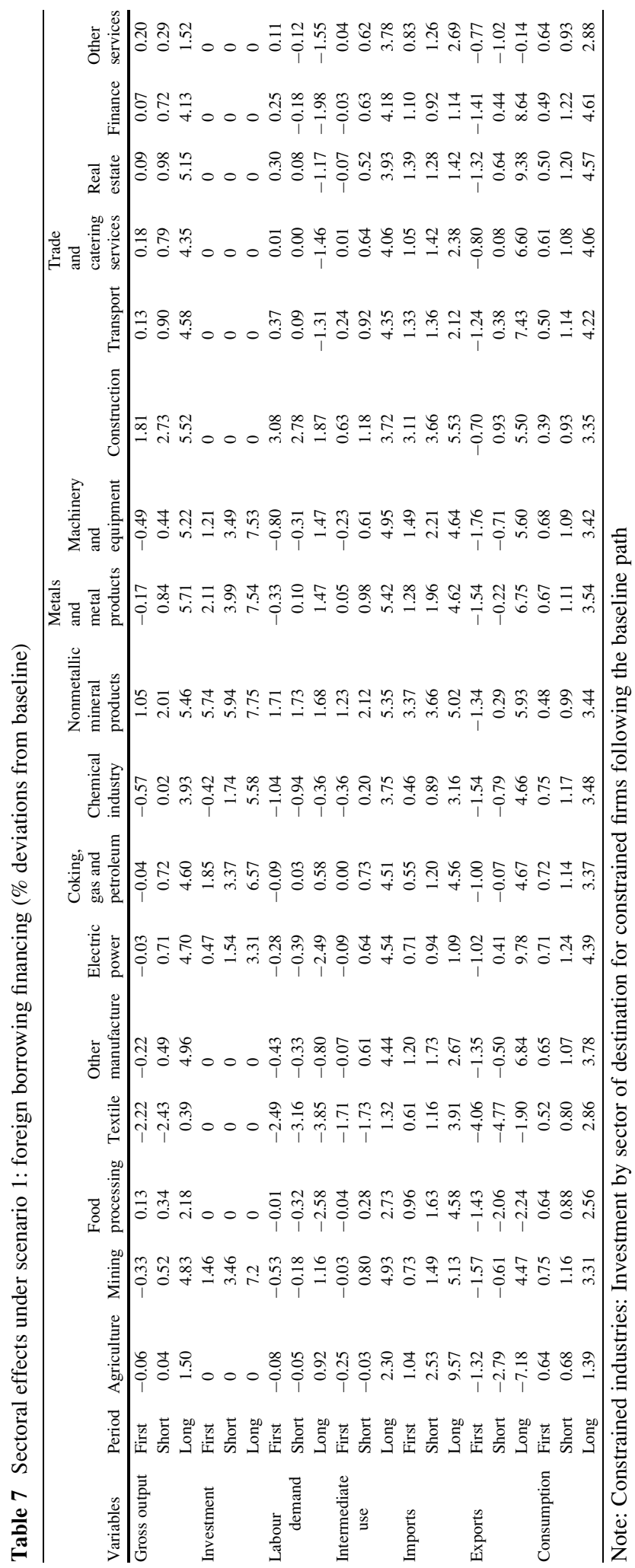


1, where foreign financing of public infrastructure investment led to a $0.01 \%$ decline in real GDP in the first period.

In the short and the long-run, the increase in public infrastructure investment improves the productivity of private capital and labour, and thus increases output. Enhanced productivity brings higher returns to labour and capital. The wage rate increases in the short-run $(0.07 \%)$ and in the long-run $(5.74 \%)$. Similarly, the capital rental rate of constrained households rises in the short-run $(0.07 \%)$ and the long-run $(0.132 \%)$.

In the short-run, the positive effects of improved productivity cannot entirely offset the negative effects of the higher production tax rate, and the stock of public capital is only $5.25 \%$ higher than in the baseline. Although the crowding out effects gradually weaken over time, the disposable income of constrained households and investment among constrained firms remain below their baseline values in the short-run.

Continuous increases in public capital stocks exert an increasingly larger positive effect on productivity. The positive effects outpace the negative effects of the production tax in the long-run. Public capital increases by $25.31 \%$ in the long-run and the disposable income of constrained households rises by $4.54 \%$. The negative effects on the consumption of the constrained households gradually become smaller and eventually become positive due to increased disposable income.

Because the constrained households consume a fixed proportion of their income, their consumptions increase at the same growth rate of income. In the short-run, the growth rate of their consumptions is relatively slow due to the negative impacts from the increased production tax. While the non-constrained households can smooth their consumption, in the short-run their consumption does not change substantially. As a result, we note that the percentage increase in the consumption of constrained households is less than that of non-constrained households in the short-run. In the long run, non-constrained households benefit of the higher investment return due to the increased public investment in infrastructure. Thus, they devote more income for investment, resulting in a growth rate of consumption lower than that of income. In the long-run, the percentage increase in the consumption of constrained households is larger than that of the non-constrained households (4.54\% vs. $2.65 \%$ respectively).

The crowding out effects eventually fade away completely. Constrained and non-constrained firms respectively increase their investments by $4.56 \%$ and $6.89 \%$ in the long-run (see Fig. 3). Both imports and exports rise by about $5 \%$ in the longrun. As a result, real GDP is $0.32 \%$ and $4.32 \%$ in the short and the long-run. Under both financing mechanisms, distortions happen only in the first period and the shortrun. Also, as expected, under the foreign financing mechanism distortions are smaller and shorter than under the production tax scheme.

Sectoral Effects: As in scenario 1, sector-specific impacts occur in the first time period, as presented in Table 8 . Infrastructure investment financed by the production tax increases the tax burden on firms, reducing their demand for intermediate use in almost all sectors in the first period, except for the construction and nonmetallic mineral product sectors. The following sectors see their use as a production intermediate decline: mining $(0.22 \%)$, textiles $(0.89 \%)$ and the manufacture of machinery and equipment production $(0.36 \%)$. 


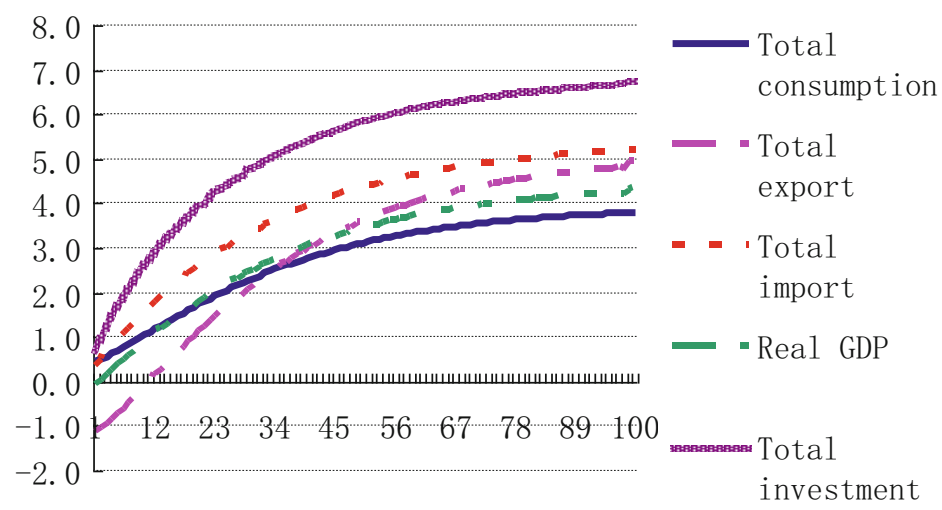

Fig. 3 GDP: demand-side effects (production tax financing) (Source: Model results)

Crowding out effects on private investments are reflected at the sectoral level in the immediate period. The new investments are reallocated among sectors according to sectoral returns to private capital. The level of investment declines in most sectors, except in the nonmetallic mineral product sector, which experiences a $2.08 \%$ increase. This is very different from scenario 1. Investment increases in most sectors in the first scenario, and especially investment in the nonmetallic mineral product sector increases by $5.74 \%$.

The same is observed for labour demand. The demand for labour in most sectors shrinks in the first period due to a lower marginal product of labour. For example, labour demand in the textiles, electric power and machinery and equipment sectors fall the most, respectively by $1.10 \%, 0.80 \%$ and $0.79 \%$, while positive effects on labour demand are observed in the construction $(1.17 \%)$ and nonmetallic mineral product $(0.50 \%)$ sectors.

The decline of constrained households' disposable income leads to lower household consumption among these households, while non-constrained households' consumption demand increases slightly (less than $1 \%$ ) across all sectors in the first period as a result of having the ability to smooth their consumption. Total domestic demand thus decreases in some sectors and increases in others.

The shocks to international markets are felt most strongly in the textiles sector, with a $2.04 \%$ decline in its exports and a $0.28 \%$ increase in imports in the first period. The shock affects other sectors, such as machinery and equipment, metals and metal products. The agricultural and other services sectors see the opposite effect, with a decrease in imports and an increase in exports.

In the first period, agriculture, food processing, nonmetallic mineral products, construction, transport, real estate, finance and other services see output gains from higher public infrastructure investment, while other sectors register losses. In particular, the output of the construction, other services and manufacturing of nonmetallic mineral product sectors respectively increases by $0.64 \%, 0.36 \%$ and $0.26 \%$ in the first period. Meanwhile, production in the textiles and machinery and equipment sectors respectively fall by $1.12 \%$ and $0.54 \%$. 


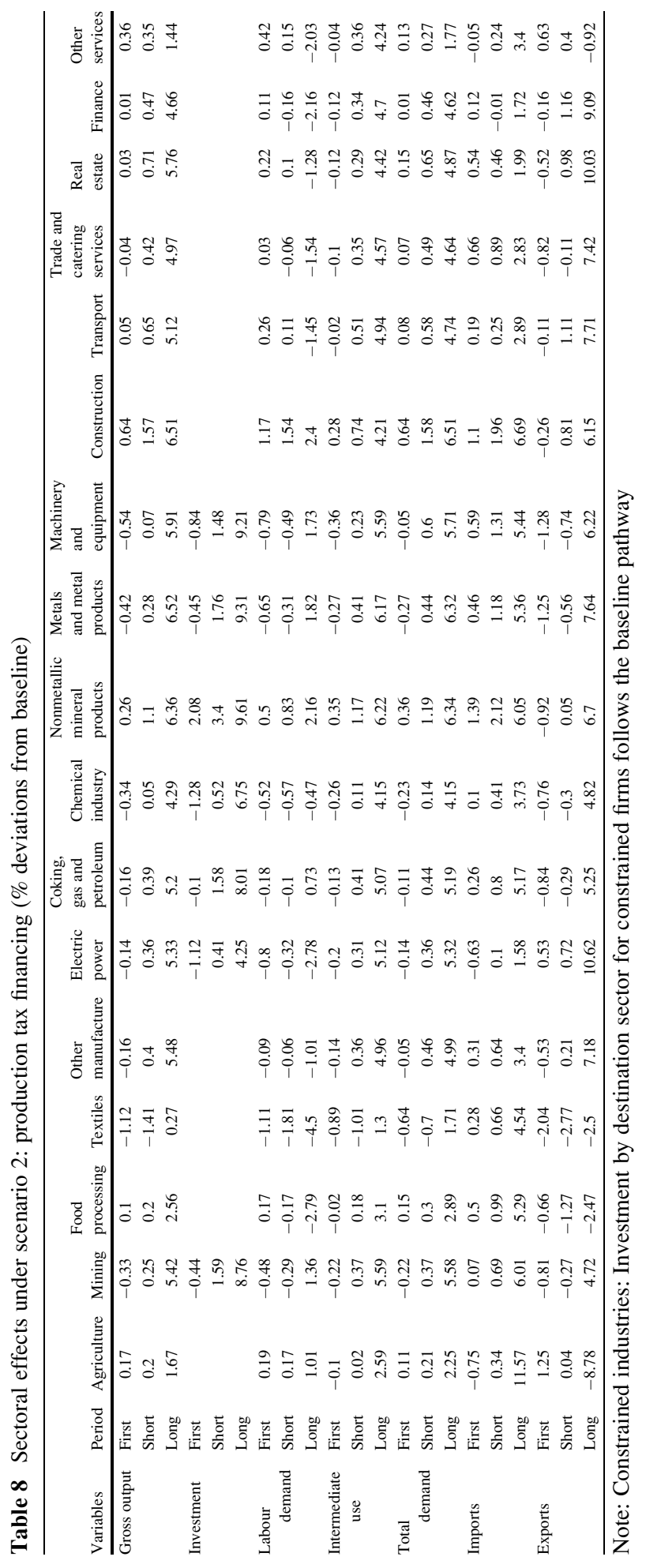


Most of the adverse impacts of tax-financed public infrastructure investment occur in the first period. In the short and the long-run, the additional public investment accumulates into a larger stock of public capital, generating positive effects on sectoral productivity. This resulting gradual increase in sectoral productivity helps attract additional investment in every sector. In the long-run, this leads to higher production in every sector. For example, the construction, manufacture, and processing of metal and metal products sectors' see a substantial increase in their long-run output of about $6 \%$. The textiles sector, which contracts the most in the first period, eventually recovers to register a $0.27 \%$ higher production in the long-run relative to the baseline.

\section{Sensitivity Analysis}

A sensitivity analysis is conducted to see whether the results of the model are sensitive to the choice of the model's elasticity. The output elasticity of public capital stock is the most important parameter underlying the productivity of public infrastructure investments. The elasticity used in the model $(0.15)$ is tested against a lower (0.1) and higher (0.2) elasticity. Several important results of the sensitivity analysis are presented in Table 9. While the size of the effects differ, similar patterns result from these public capital stock production elasticities. Nonetheless, a higher output elasticity of public capital means stronger policy results. For example, increasing the public capital stock production elasticity from 0.1 to 0.2 raises real GDP from 2.53 to $5.22 \%$ higher (see Table 9).

The production function and trade elasticities are also tested in our study, and the results are robust. The sensitivity results are not presented in full for brevity.

\section{Microsimulation Results}

The distributive effects are determined via the microsimulation module. Both the poverty and inequality effects are calculated for the two scenarios: the first is financed by foreign financing and the second is financed by a production tax.

\section{Poverty Effects}

The poverty effects are assessed against the base year using the international poverty line of $\$ 1.25$ per day. The results are presented in Table 10. The two financing mechanisms lead to different results in terms of poverty changes in the first period. For example, the poverty headcount ratio increases under the production tax but it decreases under foreign financing. However, with enhanced productivity due to increased PII, the two financing mechanisms both help reduce poverty 


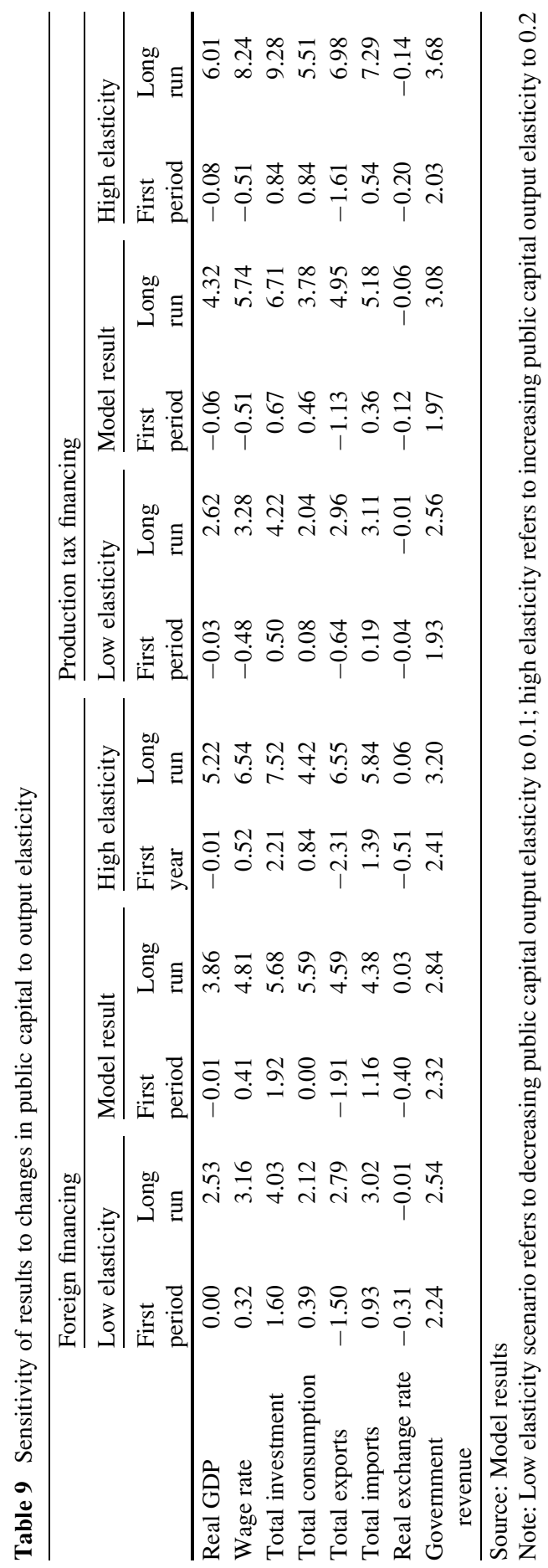


Table 10 Poverty headcount and effects of higher PII on poverty (international line of $\$ 1.25 /$ day)

\begin{tabular}{|c|c|c|c|c|c|c|c|c|}
\hline \multirow[t]{2}{*}{$\begin{array}{l}\text { National P0 (wrt base } \\
\text { year, \%) }\end{array}$} & \multicolumn{8}{|l|}{24.70} \\
\hline & \multicolumn{4}{|c|}{ Foreign financing } & \multicolumn{4}{|c|}{ Tax financing } \\
\hline \multirow[t]{2}{*}{ Period } & $1 \mathrm{st}$ & 5 th & 20 th & 100th & $1 \mathrm{st}$ & 5 th & 20th & 100th \\
\hline & \multicolumn{8}{|c|}{ Total change (in $\%$ points) in $\mathrm{P} 0$ : } \\
\hline Total & -0.04 & $-0.46^{\mathrm{a}}$ & $-1.38^{\mathrm{a}}$ & $-2.23^{\mathrm{a}}$ & $0.21^{\mathrm{a}}$ & $-0.04^{\mathrm{a}}$ & $-1.07^{\mathrm{a}}$ & $-2.65^{\mathrm{a}}$ \\
\hline Non-constrained & 0.04 & -0.17 & $-0.97^{\mathrm{a}}$ & $-1.50^{\mathrm{a}}$ & 0.19 & -0.03 & $-0.58^{\mathrm{a}}$ & $-1.78^{\mathrm{a}}$ \\
\hline \multirow[t]{2}{*}{ Constrained } & -0.07 & $-0.53^{\mathrm{a}}$ & $-1.49^{\mathrm{a}}$ & $-2.42^{\mathrm{a}}$ & $0.21^{\mathrm{a}}$ & -0.04 & $-1.20^{\mathrm{a}}$ & $-2.87^{\mathrm{a}}$ \\
\hline & \multicolumn{8}{|c|}{ Change (in $\%$ points) in $\mathrm{P} 0$ due to change in: } \\
\hline Wage & $-0.13^{\mathrm{a}}$ & $-0.38^{\mathrm{a}}$ & $-1.09^{\mathrm{a}}$ & $-1.51^{\mathrm{a}}$ & $0.17^{\mathrm{a}}$ & -0.01 & $-0.74^{\mathrm{a}}$ & $-1.87^{\mathrm{a}}$ \\
\hline $\begin{array}{l}\text { Self-employment } \\
\text { revenue }\end{array}$ & $-0.10^{\mathrm{a}}$ & $-0.22^{\mathrm{a}}$ & $-0.79^{\mathrm{a}}$ & $-1.07^{\mathrm{a}}$ & $0.06^{\mathrm{a}}$ & $-0.04^{\mathrm{a}}$ & $-0.55^{\mathrm{a}}$ & $-1.34^{\mathrm{a}}$ \\
\hline Own-consumption & -0.03 & $-0.10^{\mathrm{a}}$ & $-0.19^{\mathrm{a}}$ & $-0.27^{\mathrm{a}}$ & $0.06^{\mathrm{a}}$ & 0.00 & $-0.15^{\mathrm{a}}$ & $-0.47^{\mathrm{a}}$ \\
\hline Consumer prices & $0.21^{\mathrm{a}}$ & $0.36^{\mathrm{a}}$ & $0.68^{\mathrm{a}}$ & $0.79^{\mathrm{a}}$ & $-0.04^{\mathrm{a}}$ & 0.01 & $0.43^{\mathrm{a}}$ & $1.07^{\mathrm{a}}$ \\
\hline Residual & 0.01 & -0.12 & 0.01 & -0.17 & -0.04 & 0 & -0.06 & -0.04 \\
\hline Rural households P0 & 28.51 & & & & & & & \\
\hline
\end{tabular}
(wrt base year, \%)

Period
Total
Wage
Self-employment
$\quad$ revenue
Own-consumption
Consumer prices
Residual
Migrant households P0
$\quad$ (wrt base year, \%)

\section{Foreign financing}

1st 5th 20th 100th 1st 5th 20th 100th

Total change (in $\%$ points) in $\mathrm{P} 0$ :

$\begin{array}{llllllll}-0.05 & -0.51^{\mathrm{a}} & -1.59^{\mathrm{a}} & -2.58^{\mathrm{a}} & 0.23^{\mathrm{a}} & -0.05 & -1.23^{\mathrm{a}} & -3.06^{\mathrm{a}}\end{array}$

Change (in \% points) in $\mathrm{P} 0$ due to change in:

$\begin{array}{cccccccr}-0.13^{\mathrm{a}} & -0.42^{\mathrm{a}} & -1.23^{\mathrm{a}} & -1.69^{\mathrm{a}} & 0.19^{\mathrm{a}} & -0.01 & -0.82^{\mathrm{a}} & -2.07^{\mathrm{a}} \\ -0.11^{\mathrm{a}} & -0.26^{\mathrm{a}} & -0.94^{\mathrm{a}} & -1.28^{\mathrm{a}} & 0.07^{\mathrm{a}} & -0.05 & -0.66^{\mathrm{a}} & -1.60^{\mathrm{a}} \\ & & & & & & & \\ -0.04 & -0.12^{\mathrm{a}} & -0.23^{\mathrm{a}} & -0.32^{\mathrm{a}} & 0.07^{\mathrm{a}} & 0.00 & -0.18^{\mathrm{a}} & -0.57^{\mathrm{a}} \\ 0.23^{\mathrm{a}} & 0.42^{\mathrm{a}} & 0.79^{\mathrm{a}} & 0.92^{\mathrm{a}} & -0.05^{\mathrm{a}} & 0.01 & 0.50^{\mathrm{a}} & 1.23^{\mathrm{a}} \\ 0 & -0.13 & 0.02 & -0.21 & -0.05 & 0 & -0.07 & -0.05\end{array}$

2.36

\section{Foreign financing}

\section{Period}

Total

1st 5th 20th 100th

\section{Tax financing}

Total change (in \% points) in P0: Change (in \% points) in $\mathrm{P} 0$ due to change in:

Wage

Self-employment

Consumer prices

Residual

$\begin{array}{rr}-0.16 & -0.17 \\ -0.01 & -0.05 \\ 0.03 & 0.03 \\ 0.16 & -0.07 \\ 6.60 & \\ & \\ \text { Foreign financing }\end{array}$

$-0.27^{\mathrm{a}} \quad-0.44^{\mathrm{a}} \quad 0.03$

0.3

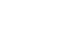

Urban household P0 (wrt base year, \%)

\section{Period}

1st 5th 20th

$$
-0.13^{\mathrm{a}} \quad-0.17^{\mathrm{a}} \quad 0.00
$$

$0.00 \quad-0.23^{\mathrm{a}} \quad-0.46^{\mathrm{a}}$

$\begin{array}{lll}0.00 & -0.23 & -0.46 \\ 0.00 & -0.11^{\mathrm{a}} & -0.17^{\mathrm{a}}\end{array}$

$\begin{array}{lll}0.03 & 0.03 \quad 0.00\end{array}$

0.00

0.03

0.03

$-0.02$

$0.15-0.01$

$\begin{array}{ll}0 & 0.01\end{array}$

0.07

Total change (in \% points) in $\mathrm{P} 0$

Total

$\begin{array}{llllllll}-0.03 & -0.20^{\mathrm{a}} & -0.38^{\mathrm{a}} & -0.58^{\mathrm{a}} & 0.09^{\mathrm{a}} & -0.01 & -0.32^{\mathrm{a}} & -0.65^{\mathrm{a}}\end{array}$

\section{Tax financing}

Change (in \% points) in $\mathrm{P} 0$ due to change in:

\begin{tabular}{lrrrrrrrr} 
Wage & $-0.14^{\mathrm{a}}$ & $-0.21^{\mathrm{a}}$ & $-0.42^{\mathrm{a}}$ & $-0.70^{\mathrm{a}}$ & $0.09^{\mathrm{a}}$ & 0.00 & $-0.32^{\mathrm{a}}$ & $-0.91^{\mathrm{a}}$ \\
Self-employment & -0.04 & -0.04 & $-0.07^{\mathrm{a}}$ & $-0.07^{\mathrm{a}}$ & 0.00 & -0.03 & $-0.06^{\mathrm{a}}$ & $-0.1^{\mathrm{a}}$ \\
Consumer prices & $0.08^{\mathrm{a}}$ & $0.09^{\mathrm{a}}$ & $0.18^{\mathrm{a}}$ & $0.19^{\mathrm{a}}$ & -0.01 & 0.01 & $0.10^{\mathrm{a}}$ & $0.29^{\mathrm{a}}$ \\
\hline & & & & & & & &
\end{tabular}


Table 10 (continued)

National P0 (wrt base

year, \%)

24.70

\begin{tabular}{lcccccccr}
\hline & \multicolumn{7}{c}{ Tax financing } \\
\hline Residual & 0.07 & -0.04 & -0.07 & 0 & 0.01 & 0.01 & -0.04 & 0.07 \\
\hline
\end{tabular}

Note: The base poverty headcount indexes of the constrained and non-constrained households are respectively $24.67 \%$ and $24.84 \%$

${ }^{\mathrm{a}}$ The difference relative to the base year is statistically significant at the $10 \%$ level

in both the short run and long run. In the long run, for example, the overall poverty headcount ratio falls by 2.23 percentage points in the foreign borrowing scenario (scenario 1 ), and by 2.65 percentage points in the production tax scenario (scenario 2 ). The poverty headcount for rural households falls by 2.58 percentage points in the long run in scenario 1 and by 3.06 percentage points in scenario 2 . The poverty reductions among urban and migrant households are also quite significant. For example, under the production tax financing mechanism, the poverty headcount ratios for migrant and urban households respectively decline by 0.53 and 0.65 percentage points in the long run. We also tested whether the poverty reductions relative to the base year are statistically significant using the approach in Araar and Duclos (2009). The test results are reported in Table 10. For the national sample, all poverty reductions are relative to the base year and, except for in the first period in scenario 1 , are statistically significant at the $10 \%$ level.

Higher PII is found to have different poverty effects on constrained and non-constrained households in the first period. For example, under the foreign financing mechanism, some non-constrained households exit poverty in the first period (headcount decreases by 0.07 percentage points), while some constrained households enter poverty (their headcount ratio increases by 0.04 percentage points). However, both changes relative to the base year are not statistically significant. The results show that poverty is reduced in the long run for both types of households, by 2.42 percentage points among constrained households and by 2.50 percentage points among non-constrained households. The result indicates that the increased PII has larger poverty reduction effects for constrained households than for non-constrained households, which is consistent with the macro effects. This is likely because most of the poor among constrained households are near the poverty line than among non-constrained households, making it easier for them to exit poverty. Many factors positively and negatively interact with the effects of PII on poverty (Table 10). The poverty reducing effects of PII largely arise from two sources: wage income and income from self-employment. In the long run, wages contribute to decrease the national poverty headcount ratio by 1.51 percentage points under scenario 1 and by 1.87 percentage points under scenario 2 . As shown with respect to macro effects, wages rise rapidly, by $4.81 \%$ in scenario 1 and by $5.74 \%$ in scenario 2 . It is worth noting here that wage income is the most important source of income among many poor households. Approximately $60 \%$ of households in the sample earn wage income. The rise in self-employment income is the second largest contribution to poverty reduction. Rising self-employment income reduces the long run national poverty headcount by 1.07 percentage points 
in scenario 1 and by 1.34 percentage points in scenario 2 . The increasing effects of PII on poverty are largely due to rising consumer prices. The results show that, in the long term, the rise of consumer prices induced by the PII contributes to increase the national poverty headcount by 0.79 and 1.07 percentage points under scenario 1 and scenario 2 respectively.

\section{Effects on Inequality: Gini Coefficient}

The Gini coefficient is used to show the effects of higher PII on inequality (see Table 11). The Gini coefficient in the base year is noted at the national level (0.3292) and among rural (0.3021), urban (0.3089) and migrant (0.2862) households. Real consumption expenditures are used to estimate Gini coefficients in this study, so the coefficients are smaller than those reported in studies that use real income.

Similar to the poverty effects, the inequality effects differ by scenario in the first period: equality improves under the foreign financing scenario (national Gini falls to 0.3288 ), while inequality worsens under the production tax financing scenario (Gini rises to 0.3293). The first of these effects is statistically significant, but the second is not. In both the short and long run, the gradually higher productivity due to higher public investment positively affects equality in the production tax financing scenario. For example, the national Gini coefficient falls to 0.3271 in the short run and 0.3267 in the long run under the production tax financing scenario. Both of these changes are statistically significant.

Table 11 also shows the effects of PII on inequality by household group. Equality improves among both rural and urban households in the short and long run. For example, the long run Gini coefficients among rural and urban households respectively fall to 0.3004 (from 0.3021 in the base year) and 0.3078 (from 0.3089 in the base year) under the foreign financing scenario. Both decreases relative to the base year are statistically significant. However, we should mention that the inequality-reducing effect of the increased PII on migrant households is not statistically significant.

Rising rural-urban inequality is an important issue for the government. The government aims to narrow the gap between rural and urban households. The national Gini coefficient is decomposed to reveal the differing effects of higher PII on rural and urban households. The results show that the Gini coefficient between rural and urban households declines over time (see Table 11). The decrease in inequality between urban and rural areas contributes the most to the improvement in overall inequality in the long run.

\section{Conclusion and Policy Implications}

An integrated macro-micro simulation method is applied to analyze the growth and distributive effects of PII. An inter-temporal dynamic CGE model of China is developed to trace the channels whereby PII impacts economic development. The macro effects are passed on to the microsimulation model to analyze the poverty 


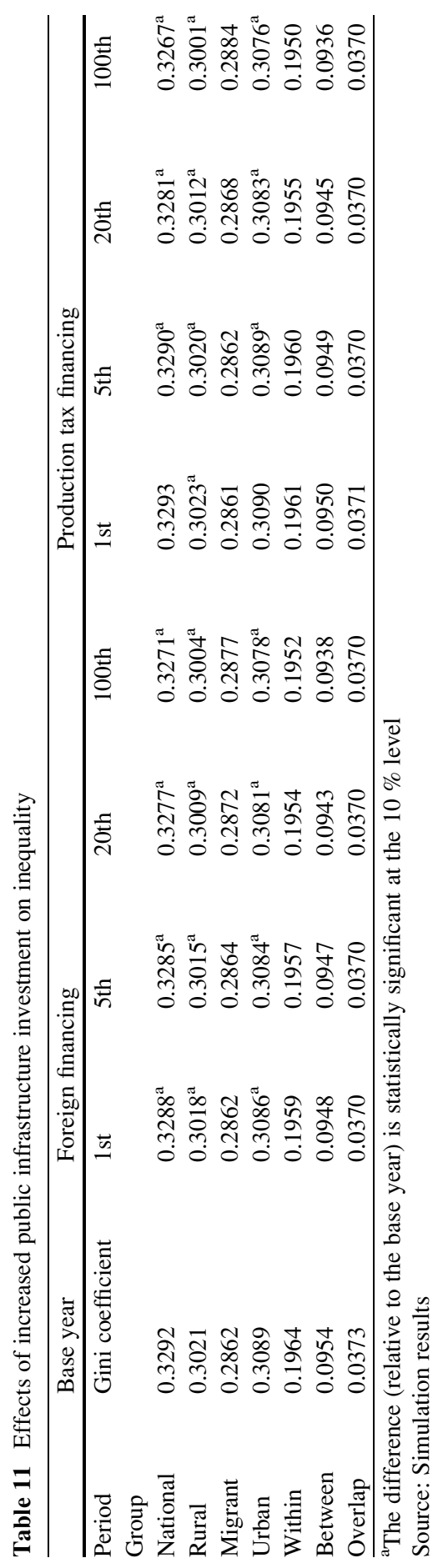


and inequality effects. A $20 \%$ increase in the PII-to-GDP ratio is simulated and two different financing mechanisms are considered to finance this additional PII: foreign borrowing and a production tax.

Although some first-year results differ in their responses to higher PII in China, the two simulation results are similar in both the short run and long run. For instance, the increase in PII has a small crowding out effect on private investment in the first period when a production tax is used to finance the PII, whereas there are virtually no negative effects under the foreign borrowing mechanism. The results show that the increase in PII not only drives economic growth, but also helps reduce poverty and inequality. Long run real GDP is found to be approximately 4 percentage points higher in response to increased PII, as a result of improved long run productivity. Sector-specific characteristics cause sectors to respond differently. For example, the construction, nonmetallic mineral products, and metal and metal products sectors gain significantly from the increased PII, while the labourintensive textiles sector loses a degree of competitiveness due to rising real wages.

In particular, PII leads to significant and positive improvements in poverty and inequality in both the short run and long run. The national poverty headcount ratio (international line of $\$ 1.25 /$ day) is more than 2 percentage points lower in the long run. Rising wages contribute the most to poverty reduction. As expected from the initial distribution of the poor within the country, the results also show that most of the people exiting poverty are from rural areas. Equality improves both among and between rural and urban households.

The conclusion that infrastructure both raises growth and lowers income inequality implies that infrastructure development may be a key win-win ingredient for poverty and inequality reduction. In addition to raising society's overall economic growth, it also helps raise the share of income earned by the poor. This suggests that infrastructure development should rank as a top priority in the poverty and inequality reduction agenda in China. In particular, in order to counter rising rural-urban income inequality, improved public infrastructure in rural areas could be a useful strategy. In other words, public infrastructure development should be considered as key strategy for inclusive growth.

Acknowledgements The authors want to acknowledge the financial and technical support from the Partnership for Economic Policy (PEP). PEP is financed by the Department for International Development (DFID) of the United Kingdom (or UK Aid) and the Government of Canada through the International Development Research Center (IDRC). This particular program of research received separate funding from the Australian Agency for International Development (AusAID). We thank participants in several PEP general meetings, the 2013 GTAP annual conference in Shanghai, the 2013 GDN annual conference in Manila and the 2012 international conference on CGE modeling - "Urbanization and Sustainable Development" - in Beijing for helpful comments. We also salute the support and advice provided by governmental and non-governmental counterparts. Dr. Chen's participation in the project was supported by China Contribution to International Food Policy Research Institute (IFPRI). The authors are also grateful to Jean-Yves Duclos, John Cockburn, Yazid Dissou, Luca Tiberti and Selma Didic for their technical support and guidance.

Open Access This chapter is distributed under the terms of the Creative Commons Attribution Noncommercial License, which permits any noncommercial use, distribution, and reproduction in any medium, provided the original author(s) and source are credited. 


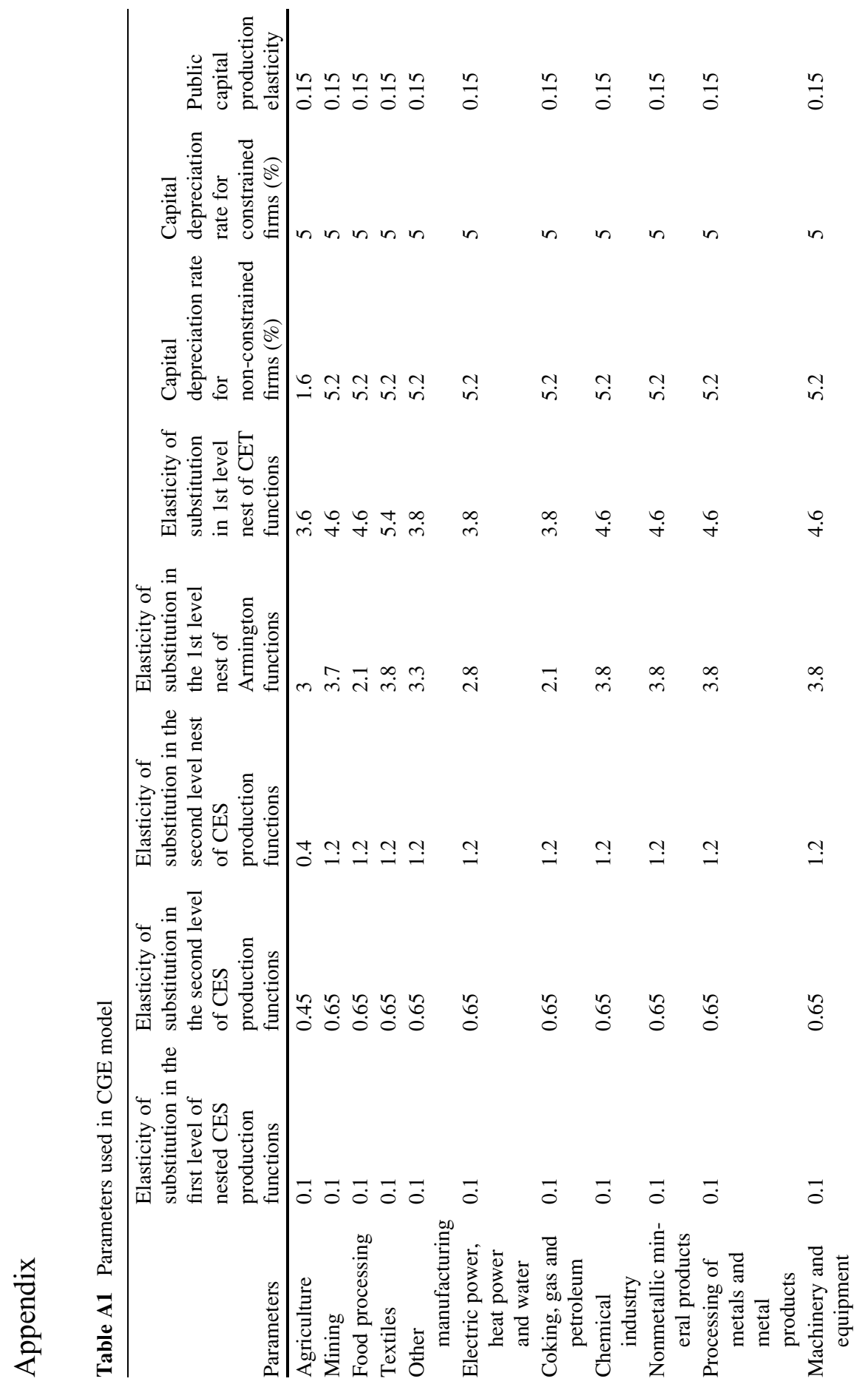




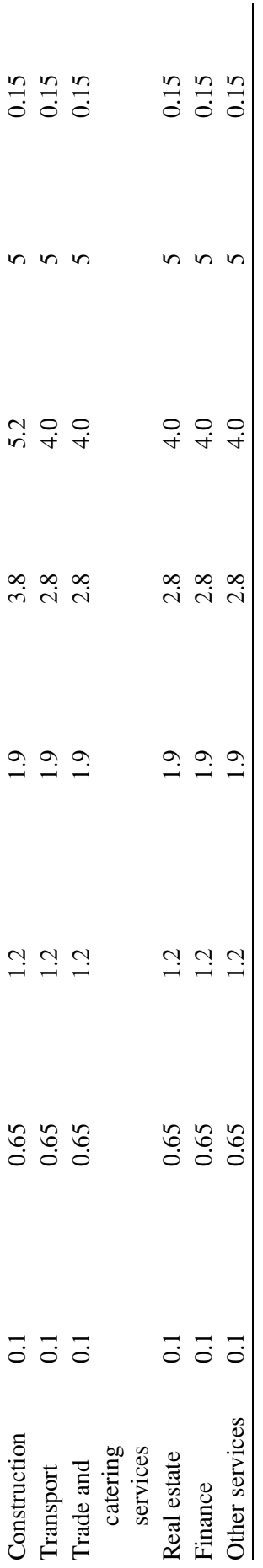




\section{References}

Adam C, Bevan D (2006) Aid and the supply side: public investment, export performance and Dutch disease in low income countries. World Bank Econ Rev 20(2):261-290

Agenor PR, Moreno-Dodson B (2006) Public infrastructure and growth: new channels and policy implications. World Bank Policy Research Working Paper 4064, World Bank

Antwi-Asare T, Cooke EF, Twerefou DK, Cockburn J, Fofana I (2010) Simulating the impact of the global economic crisis and policy responses on children in Ghana. Innocenti Working Paper IWP-2010-05

Araar A, Duclos JY (2009) DASP: Distributive Analysis Stata Package. User manual. DASP Version 2.1. University Laval, PEP, CIRPEE and World Bank

Argimon I, Gonzalez-Paramo J, Martin M, Roldan J (1994) Productivida de infrasestructuras en la economia Espanola. Moneday Credito 52:198-207

Aschauer D (1989) Is government spending productive. J Monetary Econ 23:177-200

Asian Development Bank (2003) Economic development and integration in Asia and Latin America. http://www.adbi.org/files/2003.09.29.cmats.laeba.shixue.paper.pdf. Accessed 20 Apr 2012

Asian Development Bank (2007) Toward a new Asian Development Bank in a New Asia: report of the Eminent Persons Group. http://www.adb.org/sites/default/files/pub/2007/new-adb-newasia-epg-report.pdf. Accessed 20 May 2012

Balisacan AM, Pernia EM (2002) Probing beneath cross-national averages: poverty, inequality, and growth in the Philippines. Working Paper, Series No.7, Economics and Research Department of Asian Development Bank (ERD)

Barro RJ (1990) Government spending in a simple model of endogenous growth. J Polit Econ 5:103-125

Bibi S, Cockburn J, Fofana I, Tiberti L (2010) Impacts of the global crisis and policy responses on child wellbeing: a macro-micro simulation framework. Innocenti Working Paper No. 2010-06, UNICEF Regional Office for West and Central Africa, Dakar, and UNICEF Innocenti Research Centre, Florence

Birdsall N (2007) Reflections on the macro foundations of the middle class in the developing world. Working Paper 130, Centre for Global Development, Washington, DC

Boccanfuso D, Decaluwe B, Savard L (2008) Poverty, income distribution and CGE microsimulation modeling: does the functional form of distribution matter? J Econ Inequal 6 (2):149-184

Brandt L, Holz C (2006) Spatial price differences in China: estimates and implications. Department of Economics, University of Toronto, Mimeo

Calderon C, Serven L (2004) The effects of infrastructure development on growth and income distribution. World Bank Policy Research Working Paper No. 3400, World Bank, Washington, DC

Central Intelligence Agency (2011) The world factbook. https://www.cia.gov/library/publications/ the-world-factbook/rankorder/2172rank.html. Accessed 3 Mar 2012

Chinese Monetary Society (2008) China financial yearbook (2008). China Finance press

Cockburn J (2001) Trade liberalization and poverty in Nepal: a computable general equilibrium micro-simulation analysis. CREFA Working Paper No. 01-18, University of Laval, Laval

Cockburn J, Corong E, Cororaton C (2010) Integrated Computable General Equilibrium (CGE) micro-simulation approach. Int J Microsimul 3(1):60-71

Cockburn J, Duclos JY, Tiberti L (2011) Notes on microsimulation model and results for Benin. PEP document prepared for the PEP-AusAID project "Simulate the distributive impacts of different growth strategies", Mimeo

Demurger S (2001) Infrastructure development and economic growth: An explanation for regional disparities in China? J Comp Econ 29(1):95-117

Dissou Y, Didic S (2011) Public infrastructure and economic growth-a dynamic general equilibrium analysis with heterogeneous agents. Department of Economics, University of Ottawa, January 2011 
Du ZX, Xiao WD, Zhan L (2010) The theory, meaning and policy implication to inclusive growth. China Rural Econ (in Chinese) 11:4-14

Essama-Nssah B, Go D, Kearney M, Korman V, Robinson S, Thierfelder K (2007) Economy wide and distributional impacts of an oil price shock on the South African economy. World Bank Policy Research Working Paper 4354, The World Bank, Washington, DC

Estache A, Fay M (2010) Current debates on infrastructure policy. In: Spence M, Leipziger D (eds) Globalization and growth: implications for a post-crisis world. The World Bank, Washington, DC, pp 151-194

Fan SG, Zhang LX, Zhang XB (2002) Growth, inequality, and poverty in rural China: The role of public investment. Research Report 125, International Food Policy Research Institute, Washington, DC

Fan S, Zhang X (2004) Infrastructure and regional economic development in rural China. China Econ Rev 15(2):203-214

Food and Agriculture Organization (2011) The state of food insecurity in the world 2011: How does international price volatility affect domestic economies and food security? http://www. fao.org/docrep/014/i2330e/i2330e00.htm

Ganesh R, Kanbur R (2010) Inclusive development: two papers on conceptualization, application, and the ADB perspective. Working Paper 2010-01, Department of Applied Economics and Management, Cornell University, Ithaca

Gao Y, Li ST (2006) The infrastructure construction and poverty reduction in rural China: A simulation analysis within a CGE model framework. J Quan Technical Econ (in Chinese) 6:14-24

Herault N (2010) Sequential linking of computable general equilibrium and microsimulation models: a comparison of behavioural and reweighting techniques. Int J Microsimul 3(1):35-42

Higgins K, Prowse S (2010) Trade, growth and poverty: making aid for trade work for inclusive growth and poverty reduction. Working Paper No. 313, Overseas Development Institute, London

Horridge M, Wittwer G (2007) The economic impacts of a construction project, using SinoTERM, a multi-regional CGE model of China. General Working Paper No. G-164, June 2007

Huang Q, Dawe D, Rozelle S, Huang J, Wang J (2005) Irrigation, poverty and inequality in rural China. Aust J Agric Resour Econ 49:159-175

Huang ZH (2011) Inclusive development and China transformation. People's Forum (in Chinese) 4:60-61

Jalilian H, Weiss J (2004) Infrastructure, growth and poverty: some cross-country evidence. Paper prepared for ADB Institute annual conference on infrastructure and development: poverty, regulation and private sector investment, Tokyo, Japan, 6 Dec 2004

Khandker SR, Bakht Z, Koolwal GB (2009) The poverty impact of rural roads: evidence from Bangladesh. Econ Dev Cult Change 57:685-722

Kwon E (2005) Infrastructure, growth and poverty reduction in Indonesia: a cross-sectional analysis. Paper presented at the ADBI workshop on transport infrastructure and poverty reduction, ADB, Manila, 18-22 July 2005

Li S, Luo CL (2010) Re-estimating the income gap between urban and rural households in China. In: Whyte MK (ed) One country, two societies: the urban-rural dichotomy in contemporary china. Harvard University Press, Cambridge, MA

Lokshin M, Yemtsov R (2005) Has rural infrastructure rehabilitation in Georgia helped the poor? World Bank Econ Rev 19(2):311-333

Liu LW (2003) The role of infrastructure investment to economy growth. Dissertation, Jiang Xi (in Chinese), University of Finance and Economy, Nanchang, Jiangxi, China

Liu Y (2009) A study on the problems of public investment in China. Dissertation, Hua Zhong (in Chinese), University of Science \& Technology

Ma YS (2000) The empirical analysis of the China's public capital and the growth of privatesector. Econ Sci 6:21-26

Ma SC, Li H, Yuan GM, Han YH (2001) Quantitative analysis of effects of transportation infrastructure investment on national economy. Stat Research (in Chinese) (10):30-33 
McKay A, Sumner A (2008) Economic growth, inequality and poverty reduction: Does pro-poor growth matter. IDS In Focus 3.2, Institute of Development Studies, Brighton: UK

Mu R, Van De Walle D (2007) Rural roads and poor area development in Vietnam. World Bank Policy Research Working Paper 4340, Human Development and Public Services Team, Development Research Group, The World Bank

Munnell AH (1990) Why has productivities growth declined? Productivity and public investment. New England Econ Rev 3-22

Munnell AH (1992) Infrastructure investment and economic growth. J Econ Perspect 6 (4):189-198

National Bureau of Statistics of China (2010) China statistical yearbook, 2010. Compiled by the Department of Population, Social, Science and Technology Statistics, NBS, China Statistics Press

National Bureau of Statistics of China (2011) China statistical yearbook, 2011. Compiled by the Department of Population, Social, Science and Technology Statistics, NBS, China Statistics Press

Organization for Economic Co-operation and Development (2006) Challenges for China's public spending: Toward greater effectiveness and equity, OECD 2006, Multilingual Summaries

Otto G Voss GM (1994) Public capital and private sector productivity. Econ Rec 70:121-132

Ravallion M, Chen SH (2007) China's (uneven) progress against poverty. J Dev Econ 82(1):1-42

Ramirez MD (2002) Public capital formation and labor productivity growth in Mexico. Atlantic Econ J 30(4): 366-379

Ratner JB (1983) Government capital and the production function for U.S. private output. Econ Letters 13:213-217

Rioja FL (1999) Productiveness and welfare implications of public infrastructure: a dynamic two-sector general equilibrium analysis. J Dev Econ 58(2):387-404

Sahoo P, Dash RK (2009) Infrastructure development and economic growth in India. J Asia Pac Econ 4:351-365

Sahoo P, Dash R, Nataraj G (2010) Infrastructure development and economic growth in China. 760 IDE Discussion Paper 261, Institute of Developing Economies (IDE), JETRO

Sahoo P, Dash R, Nataraj G (2010) Infrastructure development and economic growth in China. IDE Discussion Paper 261

Sicular T, Yue XM, Gustafsson B, Li S (2007) The urban-rural income gap and inequality in China. Rev Income Wealth 53(1):93-126

Song CP (2011) The regional macroeconomic effects of public infrastructure in China. Dissertation, George Mason University

Vos R, Sanchez M (2010) A non-parametric microsimulation approach to assess changes in inequality and poverty. Int J Microsimul 3(1):8-23

World Bank (2009) China - From poor areas to poor people: China's evolving poverty reduction agenda - an assessment of poverty and inequality in China. Report No. 47349CN,http://documents.shihang.org/curated/zh/2009/03/12752224/china-poor-areas-poor-peo ple-chinas-evolving-poverty-reduction-agenda-assessment-poverty-inequality-china-vol-22-executive-summary

World Economic Forum (2011) The global competitiveness report 2011-2012, Geneva

Wu GQ, Yang YQ (2003) The estimation of the public capital supply in deflationary period. Finance Econ 2:20-25

Wu YR (2009) China's capital stock series by region and sector. Discussion Paper 09.02, The University of Western Australia

Zhai F, Hertel T (2005) Impacts of the doha development agenda on China: The role of labor markets and complementary education reforms. World Bank Policy Research Working Paper 3702, September 2005

Zhang Y, Wan GH (2004) Liquidity constraint, uncertainty and household consumption in China. Applied Econ 36:2221-2229 